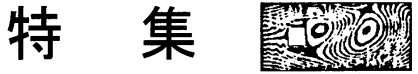

\section{エーロゾル輸送モデルの開発と現業黄砂予報への応用 \\ Development of an Aerosol Transport Model and Its Application to the Operational Asian Dust Forecast}

田中泰宙*

Taichu Y. TANAKA

\section{1.はじめに}

大気中に浮遊している微粒子は、地球の大気環境 と気候の形成に対して大きな役割をもっている。大 気中に微粒子が浮遊している系はエーロゾル、浮遊 している粒子はエーロゾル粒子と呼ばれる。エーロ ゾル粒子は、人間の活動による放出や鈗物・海塩な ど多種多様な起源をもち、それに伴って様々な種類 と形態をもち、大きさは半径がおおよそ $1 \mathrm{~nm}$ $100 \mu \mathrm{m}$ と非常に広い範囲にわたっている。大気中に 浮遊しているエーロゾル粒子は、日射を直接的に散 乱・吸収すること、また雲粒を形成する凝結核や水 晶核として作用し雲の光学的特性を変化させること によって、大気や地表面の放射収支に影響を与えて

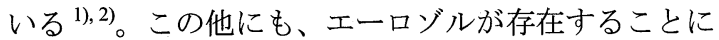
よってオゾンなど大気微量気体の化学反応が影響を

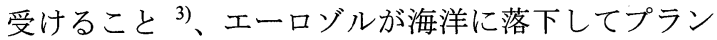
クトンへの栄養塩となり植物プランクトンの光合成 量を通じて間接的に大気中の二酸化炭素量に影響を 与えること ${ }^{4)}$ 、また積雪や水床面に沈着してその表 面を污し反射率(アルベド)を変化させ放射収支を変


響を与えている。エーロゾルによる気候への影響は 観測や数值モデルによる定量的な評価が難しく、気 候変動研究においての不確定因子となっている ${ }^{6}$ 。

また、エーロゾルは大気污染などの大気環境の上 でも大切な問題となっている。工業活動によって生 成されるエーロゾルは大気污染の原因となり、人間 の生活環境に多大な影響を及ぼしている。日本では 春の風物詩として知られている黄砂現象も、乾燥し た土壌から巻き上げられるダストエーロゾルに起因
するものである。黄砂の発源地である砂漠地帯では 砂塵嵐による家畜や家屋への甚大な被害が報告され ており、また日本のように発源地から離れた地域に おいても、視程の悪化による交通機関への影響や、 呼吸器系などの健康上の影響、精密機器への影響な ぞ、様々な問題が引き起こされる可能性が懸念され ている。特に 2000 年から 2002 年にかけて大規模な黄 砂現象が連続して多く発生したことから、黄砂問題 への社会的な関心も高まっている ${ }^{7}$ 。

このようなエーロゾルによる気候と環境への影響 を研究するため、気象モデルに大気微量物質のモデ ルを組み合わせた大気化学輸送モデル(Chemical Transport Model; CTM)の開発とそれを用いた研究が 現在活発に行われている。大気化学輸送モデルとは, 風速や気温などのデータを元にして大気中の微量物 質の分布を計算する数值モデルであり，そのような 微量物質の物理的・化学的なプロセスの理解とそれ らの気候への影響を定量的に評価するために不可欠 なツールである。気象研究所では, エーロゾルやオ ゾンなどの大気微量物質の監視や気候への影響を明 らかにするため, 全球大気化学輸送モデルの開発に 取り組んでいる。開発されているモデルは二種類存 在し、一つはエーロゾルとその関連物質を扱うエー ロゾル化学輸送モデル ${ }^{8)}$ 、もう一つはオゾンとその 関連物質の化学過程を扱うオゾン光化学モデル $(\mathrm{MRI}-\mathrm{CCM})^{9)}$ である。これらのモデルは大気化学と 物質輸送の研究に用いられるとともに、エーロゾル モデルは 2004 年 1 月から黄砂情報に、オゾンモデル は 2005 年 5 月から紫外線情報の業務にそれぞれ応用 されている。 
エーロゾルの研究はエーロゾル粒子の微物理や大 気化学分野とともに、流体力学分野とも密接に関連 している。特に、境界層内の流れは、ダストや海塩 などのエーロゾル粒子の発生や、地表起源のエーロ ゾル粒子とその前駆気体の自由対流圈への輸送過程 に大きな影響をもつ。ダストと海塩エーロゾルは大 気中のエーロゾルの質量では大部分を占めるため、 風によるこれらのエーロゾルの生成の役割は非常に 大きいといえる。本稿では、気象庁におけるエーロ ゾル輸送モデルの開発の現状と黄砂予報など現業へ の応用について解説するとともに、風環境的な観点 からの今後の研究への展望を述べる。

\section{2. 気象研究所エーロゾル輸送モデル}

\section{モデルの構成}

気象研究所のエーロゾル化学輸送モデルは Model of Aerosol Species in the Global Atmosphere (MASINGAR) と名付けられた全球 3 次元モデルで、大気大循環モ デル(atmospheric general circulation model, AGCM) と化 学輸送モデルとがオンライン結合された形となって (るる ${ }^{8)}$ 10)。すなわち、AGCM で計算された風速・気

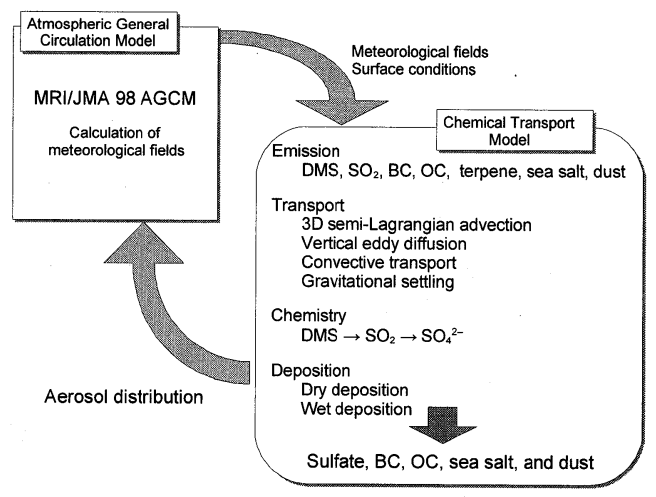

図 1. MASINGAR の構造の概念図

圧・気温・地表面状態などの気象要素を元に CTMに よってエーロゾルの発生・輸送・沈着を計算し、求 められたエーロゾル分布を AGCM へフィードバック し、放射場への影響を取り入れるように結合された 構造になっている(図 1)。このモデルの基となる大気 大循環モデルには気象研究所と気象庁で共同開発さ れた MRI/JMA98 AGCM ${ }^{11)}$ を用いている。

モデルの解像度は用途に応じて変更することがで きる。数年から数十年の長期にわたる数值実験では 主に水平格子間隔 $1.875^{\circ}$ 、鉛直 30 層（地表から $0.4 \mathrm{hPa}$ まで)で積分を行っている。黄砂予報業務では 細かな地形や地表面特性の変化を表現するため、水 平格子間隔 $1.125^{\circ}$ 、鉛直 20 層 (地表から約 $45 \mathrm{hPa}$ ま で）と設定している。

大気化学輸送モデルは主として大気輸送過程・除 去過程・放出過程・化学的変質過程で構成される。 以下にモデルで扱われる各過程について述べる。
表 1. MASINGAR に含まれるエーロゾル種とその主な放 出・生成源

\begin{tabular}{l|l}
\hline $\begin{array}{c}\text { エーロゾル } \\
\text { の種類 }\end{array}$ & \multicolumn{1}{|c}{ 主な放出・生成源 } \\
\hline Sulfate & 工業・生物・火山起源を起源とする硫化ジ \\
& ×ル(DMS) や二酸化硫黄 $\left(\mathrm{SO}_{2}\right)$ の酸化 \\
Black carbon & 工業・農業・森林火災による燃焼 \\
Organic & 工業・農業・森林火災による燃焼, および \\
carbon & 生物活動によって放出される揮発性有機炭 \\
& 素(VOC)の酸化 \\
Sea salt & 海洋上での風による海塩の飛散 \\
Mineral dust & 陸面乾燥・半乾燥地帯での風による土壌粒 \\
& 子の飛散 \\
\hline
\end{tabular}

\section{扱うェーロゾルの種類}

まず大気エーゾロルは様々な放出源・生成源をも つ。このモデルでは、エーロゾル種として硫酸塩・ 黒色炭素・有機炭素・海塩・ダストを扱っている。 表 1 に, MASINGAR の放出過程で扱われているエー ロゾルの主な放出源を示す。エーロゾルとその前駆 物質の放出量は、外部の放出源データベースと大気 モデルで計算される気象場・地表面状態を用いて計 算される。硫酸塩エーロゾルは気体の酸化によって 粒子が生成される。モデルでは硫化ジメチル (DMS) や二酸化硫黄 $\left(\mathrm{SO}_{2}\right)$ から $\mathrm{OH} 、 \mathrm{H}_{2} \mathrm{O}_{2} 、 \mathrm{O}_{3}$ によって硫 酸塩粒子が生成される化学過程を扱う。炭素系エー ロゾルは燃焼によって生成されるものと、植生によ るテルペンの酸化によるものを扱う。海塩およびダ ストエーロゾルは風によって地表から直接放出され る。それらの放出・輸送・沈着の過程はその粒径に 大きく依存するため、このモデルでは大気中で輸送 されるダストを直径 $0.2-20 \mu \mathrm{m}$ の範囲で対数的に 10 個の粒径区分に分割し、それぞれを独立に扱ってい る。

\section{大気輸送過程}

\section{大規模移流}

このモデルでは、エーロゾルなど大気微量物質の

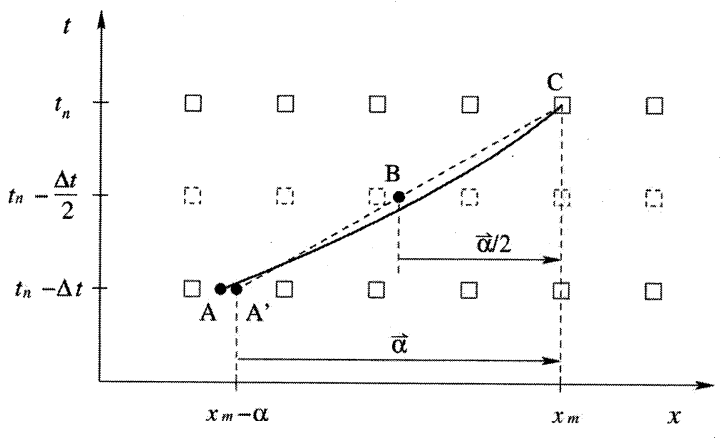

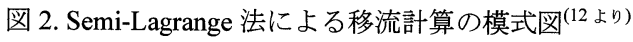


移流計算に semi-Lagrange 法 ${ }^{12)}$ を用いている。大気 微量物質の分布は非常に局所的・不連続的である場 合が多いため、Euler 法やスペクトル法による移流計 算では数值拡散や負の濃度などの誤差を生じやすく、 移流計算の時間刻みも非常に短くとる必要が生じる。 Semi-Lagrange 法とは、「時間刻み後にある格子点に 到達する空気塊はどこから来たか」を流跡をたどって 計算し、内挿計算を行うことによって移流計算を行 う方法である(図 2)。この計算方法では数值計算の安 定条件が Courant-Friedrichs-Levy (CFL)条件に拘束さ れないため長い時間刻みで安定した計算を行うこと ができること、また内挿手法を工夫することによっ て局所的な分布をもつ物質の移流計算でも比較的精 度良く計算することができるこという利点がある。 反面、Semi-Lagrange 法の欠点として質量の保存が保 障されない場合があることなどがあるが、気象研究 所で開発された semi-Lagrange 移流計算ルーチンでは、 内挿計算において高次内挿と低次内挿を組み合わせ て質量の保存が保障されるように工夫されている 9)。

\section{渦拡散による輸送}

地表面から放出される微量物質の分布を求める上 で、大気乱流による鉛直渦拡散は非常に重要な輸送 過程である。本モデルでは、大気大循環モデル

MRI/JMA 98 GCM で計算される水蒸気に対する鉛直 拡散係数を用いて微量気体とエーロゾルに対する鉛 直渦拡散を計算する。MRI/JMA 98 GCM は鉛直拡散 係数の計算に Mellor-Yamada Level 2 closure $^{13)}$ を用い ている。

本モデルでは水平方向には渦拡散輸送計算を適用 していない。これは大気の水平拡散は実際にはかな り小さく、温帯低気圧などの気象擾乱がモデルの解 像度で直接的に再現されていれば大気中での水平方 向の拡散現象は表現できると考えるためである。水 平方向の格子間隔が大きい、時間分解能が粗いなど のモデルでは、計算を安定させるために水平拡散を 導入する場合もあるが、本モデルは輸送計算にセミ ラグランジュ法を用いており計算の安定性は高く、 またモデルの時間分解能は数分から数十分程度と十 分小さいため、水平渦拡散を適用する必要はないと 考える。

\section{積雲対流による輸送}

熱的対流不安定によって発生する積雲では、雲の 内部の上昇気流の速度が数 $\mathrm{m} \mathrm{s}^{-1}$ から数十 $\mathrm{m} \mathrm{s}^{-1}$ の才 ーダーに達する。このため、滞留時間が数時間から 数日程度までの化学種の鉛直方向の分布を決定する 要因として、積雲対流による輸送は大きな影響をも つ。積雲対流による短い時間スケールの鉛直方向の 輸送の重要性は、これまで多くの研究例によって指 摘されている ${ }^{14)}$ 。また、様々なモデルで用いられて いる計算方法の比較実験から、積雲対流輸送のパラ メタリゼーションは化学輸送モデルにおける主要な 不確定性の要因の一つであることが指摘されている
14)

大気大循環モデル MRI/JMA 98 GCM は積雲対流の パラメタリゼーションに Arakawa-Schubert 法 ${ }^{15)}$ を 用いている。本モデルでは、微量気体とエーロゾル の対流による鉛直輸送に、この Arakawa-Schubert 法 で計算される質量フラックスを用いる。この方法で は、まず対流による上昇流内部の微量物質の混合比 を、上昇流の質量フラックスと微量物質の混合比に 対する質量保存の方程式を解くことによって計算す る。

\section{重力沈降}

エーロゾル粒子はおおよそ $1 \mu \mathrm{m}$ 以下の小さい粒子 の場合は、対流圈では重力による落下の影響は少な いが、粒径が数 $\mu \mathrm{m}$ 以上になるダストや海塩などの粗 大粒子や、小さい粒子でも成層圈より上層のように 大気密度の小さい場合は輸送に対して影響が大きく なる。モデルでは粒子を球形と仮定して、ストーク ス流れで求められる終端速度に、カニンガムの修正 係数 ${ }^{16), 17)}$ を考慮して重力沈降の影響を取り入れてい る。

\section{大気からの除去}

エーロゾルが大気から除去される過程は、降水に よって除去される湿性沈着と、降水を伴わず地表面 との直接の接触によって除去される乾性沈着とに大 別される。モデルでは、乾性沈着過程として、重力 による落下と地表付近での乱流で粒子が地表に衝突 する過程で、摩擦速度や地表面の粗度、粒子の落下 速度などに依存する。乾性沈着過程による除去率は 乾性沈着速度として表現し、resistance-in-series モデ ル ${ }^{18)}$ によって計算する。

湿性沈着は、雲の内部で雲粒に取り込まれ降水と なって除去される過程 (in-cloud scavenging) と、雲 底下で降水とエーロゾル粒子が衝突して除去される 過程 (below-cloud scavenging) の 2 つの過程を取り入 れている ${ }^{19,20)}$ 。湿性沈着では雲粒・雨滴とエーロゾ ル粒子の衝突効率や降水の生成率，蒸発率を元に沈 着率を計算する。

\section{大気放射との相互作用}

エーロゾルの大気放射への影響は、計算されたエ 一ロゾルの濃度とその光学的特性とをモデルの放射 過程に反映させることによって評価する。放射過程 は短波放射・長波放射に分けて計算され、それぞれ の波長帯でのエーロゾルの効果を推定することがで きる。エーロゾルの大気放射への影響は、放射計算 の時にエーロゾルがある場合とない場合を二回ずつ 計算し、その差から求める。

\section{風によるダストエーロゾルの発生過程}

黄砂はゴビ砂漠やタクラマカン砂漠・黄土高原な ど東アジアの乾燥・半乾燥地域で、低気圧活動など によって強風が吹いたときによく観測される。黄砂 の原因となる鉱物ダストの発生を支配する条件には、 
1) 地表付近での風速などの「気象の条件」と、2) 地 表面がダストを発生させうる乾燥した裸地であるこ となどの「地表面の条件」とに大別できる。

風食による土壤ダストの飛散過程の概念図を図 3 に 示す。土壌粒子の運動形態はその粒径によって異な る。大気中に長時間浮遊 (suspension) しうるのは、 おおよそ粒径が $20 \mu \mathrm{m}$ 以下の粒子で、それよりも大 きい粒子は重力沈降速度が大きいために短時間しか 浮遊できない。粒径が 70-500 $\mu \mathrm{m}$ 程度になると粒子 は地表付近を跳躍 (saltation) 運動するようになり、 さらに非常に大きい粒子 (約 $500 \mu \mathrm{m}$ 以上) は地表面 上を転動 (creep) 運動することになる。

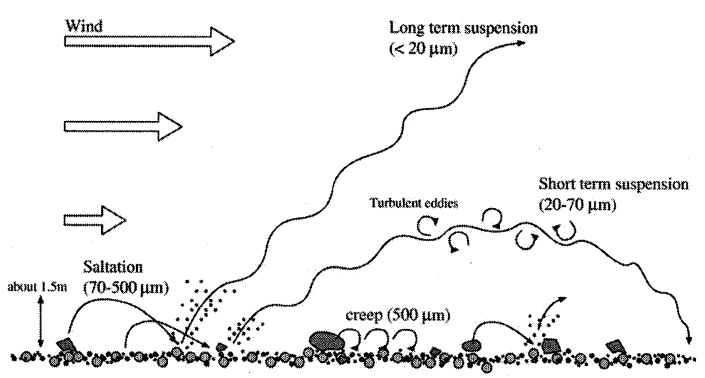

図 3. ダスト飛散の概念図 ${ }^{(26 ょ り)}$

風の摩擦力を受けて土㙵粒子が運動を始めるには、 ある闇值 (臨界風速) よりも強い風が吹くことが必要 である。非常に大きな粒子は質量が大きいため、ま た非常に小さな粒子は粒子間結合力が強いため、こ の閾值が大きく、風によっては直接大気中に飛散さ れない。最も運動を起こしやすい粒径はその中間の、 約 70-100 $\mu \mathrm{m}$ 程度の粒子である。この範囲の粒径の 粒子が跳躍運動し、地表面や粒子同士で衝突すると、 その運動エネルギーによって粒子間の結合が壊され、 長距離輸送されうる小さな粒子が大気中に放出され ると考えられている。この過程をサルテーション・ ボンバードメントという。風洞実験や理論的考察か ら、風によって起こる砂粒子のフラックスは風速 (摩擦速度) のおおよそ 3 乗に比例することが明らか

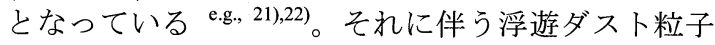
のフラックスは、風速 (摩擦速度) のおよそ 3-4 乗 に比例することが観測されている e.g., 23), 24), 25)。ダス 卜の発生が摩擦速度の幕乗に依存すること、閾值が 存在することによって、風速とダスト発生とは非線 形性の強い関係となり、わずかな風速の差が大きな 誤差に繋がる。

地表面の条件としては、具体的には積雪 - 水面 • 水面・植生の有無、土壤の特性 (粒度や種類) や土 畩水分量、塩分や有機物の含有量など、様々な要因 が含まれる。このモデルでのダストの飛散量の計算 には、積雪量や土壌水分量は大気大循環モデルに含 まれる陸面過程モデルによって計算されたものを用 い、水面の識別之植生 (Leaf Area Index (葉面積指数) を用いる) は陸面過程モデルのデータベースによっ て与えられる值を用いている。土壌が岩石主体であ
る地域は、土壌種のデータベースから識別して計算 領域から除いている。土㙵粒子の粒度分布は土性 (soil texture) のデータベースを用いて表現している。 土壤中の塩分・有機物の含有量、クラスト状に硬化 した土壌の識別などは現在のところ適切なデータベ 一スが存在しないため扱っていない。

このように、ダストの発生を予測するには地表近 くの風速 (摩擦速度) と地表面の性質 - 状態を把握 することが重要となる。気象庁黄砂予測モデルでは Tegen and Fung (1994) ${ }^{27)}$ や Takemura et al. (2000) ${ }^{28)}$ を参 考にして次式からダストの放出フラックスを計算し ている。

$$
F_{i}= \begin{cases}C M_{i} A \frac{W_{t}-W_{g}}{W_{t}}\left(U_{10}-U_{t}\right) U_{10}^{2} & U_{10} \geq U_{t} \\ 0 & U_{10}<U_{t}\end{cases}
$$

ここで $F_{i}$ は $i$ 番目の粒径区分のダストの放出量フラ ックス、 $A$ は地表面の条件によるモデル格子内で風 食の対象となる面積の割合、 $W_{g}$ は土壤水分量、 $W_{t}$ は土袞水分の闇值、 $U_{10}$ は地上 $10 \mathrm{~m}$ における風速、 $U_{t}$ は臨界風速、 $C$ は放出量の調整のための係数であ る。臨界風速 $U_{t}$ は地球大気の条件では地上 $10 \mathrm{~m}$ で約 5-7 $\mathrm{m} \mathrm{s}^{-1}$ 程度となることが観測されている。このモデ ルでは Tegen and Fung (1994) $)^{27)}$ Takemura et al. $(2000)^{28)}$ を参考に $6.5 \mathrm{~m} \mathrm{~s}^{-1}$ と設定している。なお、気 象研究所で開発中のモデルでは大気の安定性を考慮 して風速の代わりに摩擦速度を用い、土㙵の粒度分 布を考慮した上でサルテーション・ボンバードメン 卜の過程を陽に扱うダス卜放出モデルを採り入れて いる ${ }^{10), 29) 。 ~}$

\section{3. シミュレーション結果の例 \\ エーロゾルの気象場・気候への影響}

エーロゾルは種類によって光学特性が異なるため、 放射への影響の分布は複雑になる。図4 は MASINGAR によってシミュレートされた大気上端におけ るエーロゾルによる放射収支への影響の年平均值を示し ている。一般的傾向として、硫酸塩・有機炭素・海塩池 球を冷却、黒色炭素は加熱に作用している。硫酸塩・黒 色炭素・有機炭素・海塩・鉱物ダストの全球及び年間平 均の放射収支一の影響はそれぞれ $-0.54 、+0.68 、-0.39$ 、 $-0.56 、-0.18 \mathrm{~W} \mathrm{~m}{ }^{-2}$ と推定されている。エーロゾル全体 による全球・年間平均の放射への影響は $-1.07 \mathrm{~W} \mathrm{~m} \mathrm{~W}^{-2}$ と なり、全体的にはエーロゾルは地球を冷却することが示さ れている。

ダストエーロゾルの放射への影響は地表面のアルベド やダストと雲との鈶直方向の位置関係によって加熱にも 冷却にもなる。一般的には砂漠のように地表面アルベド の高い地域では加熱、海洋上や森林などアルベドの低 い地域では冷却となっている。ただし、ダストエーロゾル の光学的特性、特に吸収特性の観測值には大きな幅が 

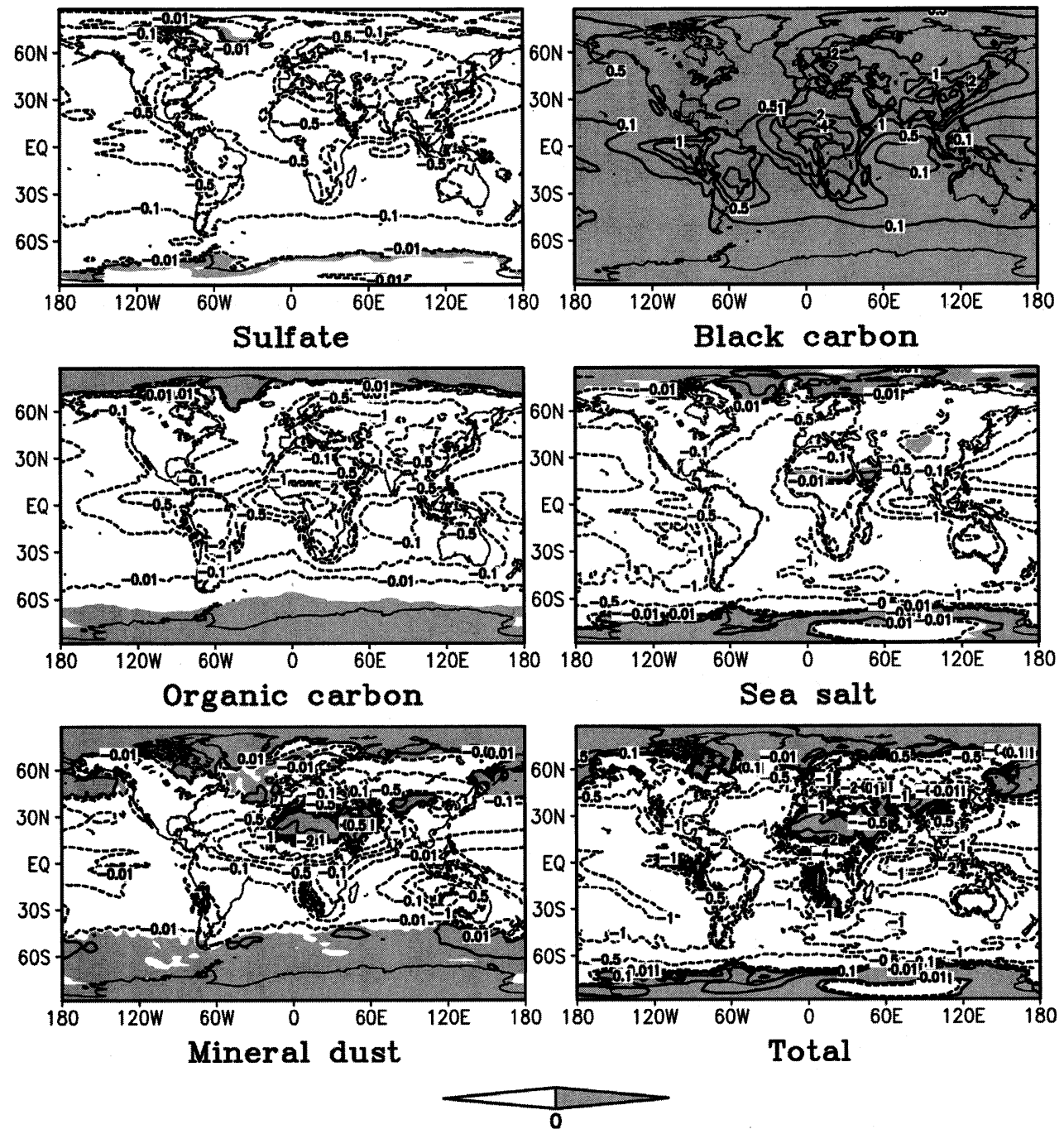

図 4. 大気上端におけるエーロゾルの放射への影響 (年平均値)。灰色の部分地球を暖める効果、白の部分は地球を冷却 する効果を示している。

ある。光学的特性によってはダストエーロゾルの放射への 影響は全球平均で加熱にも冷却にもなりうる。また、ダス トエーロゾルの放射への影響には顕著な地域差が見られ る。特にダストの多いサハラ砂漠では地表面に到達する 日射は 8-14\%も減少する ${ }^{30}$ 。ここのような大きな放射収支 への影響と大きな地域差は、地域的な気候や風環境へ も影響を及ぼすことも考えられる。

\section{2 年 3 月の黄砂現象シミュレーション}

2002 年 3 月 20-22 日には、非常に大規模なダスト現


現象では、北京における Total Suspended Particle (TSP)濃度は $11000 \mu \mathrm{g} \mathrm{m}^{-3}$ 31)、韓国における PM10 (粒 子の空気動力学的 50\%カットオフ径が $10 \mu \mathrm{m}$ の粒子) 濃度は最大 $3000 \mu \mathrm{g} \mathrm{m}^{-3}$ 32) にも達したと報告されてい る。このときの砂塵嵐を再現実験した結果の鉛直積
算量分布を図 $5 \mathrm{a}$ に、衛星センサーTotal Ozone Mapping Spectrometer (TOMS)で導出された、吸収性 のエーロゾルの指標である Aerosol Index (TOMS AI) ${ }^{33)}$ の分布を図 $5 b$ に示す。シミュレーション結果は大 陸内部では対応していない部分があるものの、 TOMS AI の高い部分とよく対応しており、中国にお ける大規模な砂塵嵐がよく再現されているといえる。 図 5c と図 5d は、シミュレーションによる地表付近 のダスト濃度を韓国の Gunsan での TSP 濃度と東ア ジア酸性雨モニタリングネットワーク (EANET) に よる利尻に扔ける PM10 濃度の時系列変化 ${ }^{34)}$ との比 較である。シミュレーションでは濃度の值を若干低 く見積もっている傾向があるが、ダストの到達と終 息のタイミングは実測值と良い一致を示している。 濃度の誤差の原因として最も影響の大きいのはダス トの発生量であると考えられる。式(1) のように、 


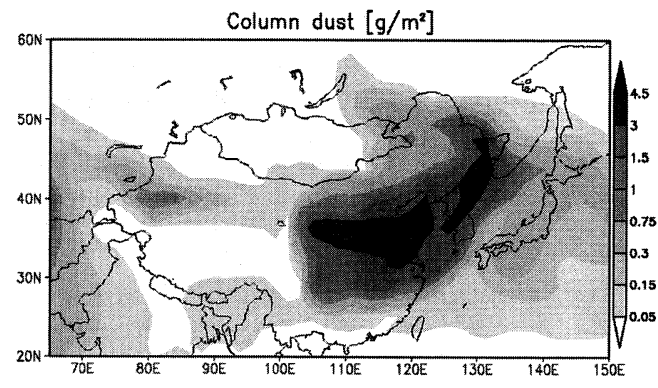

00:00Z 21 Mar 2002

(a)

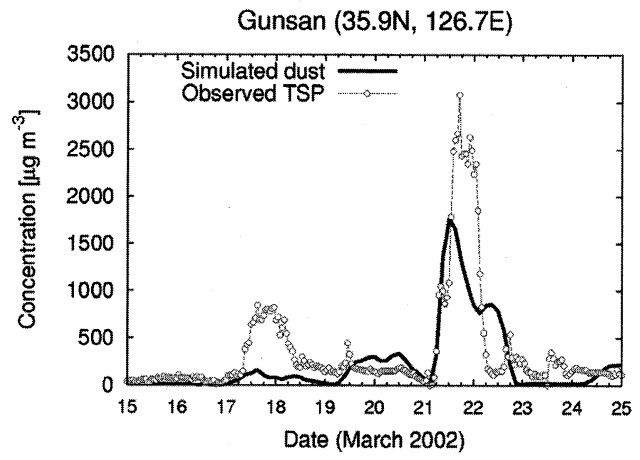

(c)



21 Mar 2002

(b)

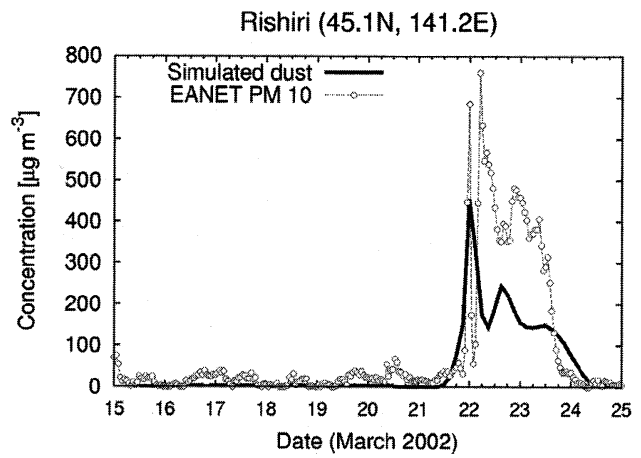

(d)

図 5. (a) モデルによる 2002 年 3 月 21 日のダスト鉛直積分量. (b) 2002 年 3 月 21 日の TOMS aerosol index. (c) 韓国 Gunsan に おけるモデルによるダスト濃度(実線)と観測による総浮遊粒子状物質量(TSP)の比較 (d)利尻におけるモデルによる ダスト濃度と PM10 との比較. Gunsan の TSP データは韓国気象庁より、利尻の PM10データは Network Center for Acid Deposition Monitoring Network in East Asia (EANET) ${ }^{34)}$ より提供.

ダストの発生量は地上風速のほぼ 3 乗に依存するた め、わずかな地上風速の誤差から大きな影響を受け やすいこと、3 月は植生や積雪量の変化が大きいこ となどが誤差の主な原因として考えられる。

\section{4. 黄砂予報業務への応用}

気象庁では 2004 年 1 月から気象情報やインターネット (http://www.jma.go.jp/jp/kosa/index.html)を通じて黄砂 現象に関する情報を提供している。図 6 は 2007 年 4 月 2 日の黄砂現象発生時の黄砂情報の例である。この 情報には黄砂現象の観測された地点の現況之、黄砂現 象の数値予報が含まれている。黄砂予測図では、日本の 周辺を一辺 1.25 度の格子に分割して、濃い黄砂 (視程が $10 \mathrm{Km}$ 末満)を予測した領域を地図上で表示している。こ の黄砂の数值予測には高解像度版 $\left(1.125^{\circ} \times 1.125^{\circ}\right)$ の MASINGAR が用いられている。

\section{黄砂現象の判定}

モデルによるダスト濃度の計算結果から黄砂現象 の予測を行うには判定の基準が必要となる。現時点 では、計算結果による黄砂の有無の判断のため、判 別の間值を設定し、予測された地表付近のダスト質 量濃度がこの閾值を上回る場合には「黄砂有り」と判 定する方法を採っている。この閯値の設定には
Equitable Threat Score (ETS) を用いる。ETS とは、ス レットスコア (現象を予測したとき、または実況でそ の現象が起こったときの予測の的中率) から気候学的 確率で的中寸る分を除いてスコアを求めたもので、 次のように定義される。

$$
\mathrm{ETS}=\frac{F O-S f}{F O+F X+X O-S f}
$$

ここで $F O$ は観測があったときの的中回数、XO は見 逃し回数、FX は空振り回数である。Sf は気候学的確 率で、

$$
S f=\frac{(F O+X O)(F O+F X)}{F O+X O+F X+X X}
$$

となる。ここで $X X$ は観測がなかったときの的中回数 である。ETS は值が大きいほど精度が良く、ランダ ム予測では 0 、最大值は 1 となる。判定基準はダスト 濃度による黄砂の有無と地上気象観測 (SYNOP) 報 による黄砂の有無の ETS が極大になるように設定す る。現在のモデルでは閾値は $150 \mu \mathrm{g} \mathrm{m}^{-3}$ と設定してい る。

\section{5. 黄砂予測モデルの課題点}

最後に黄砂予測における課題点を、特に風環境工 


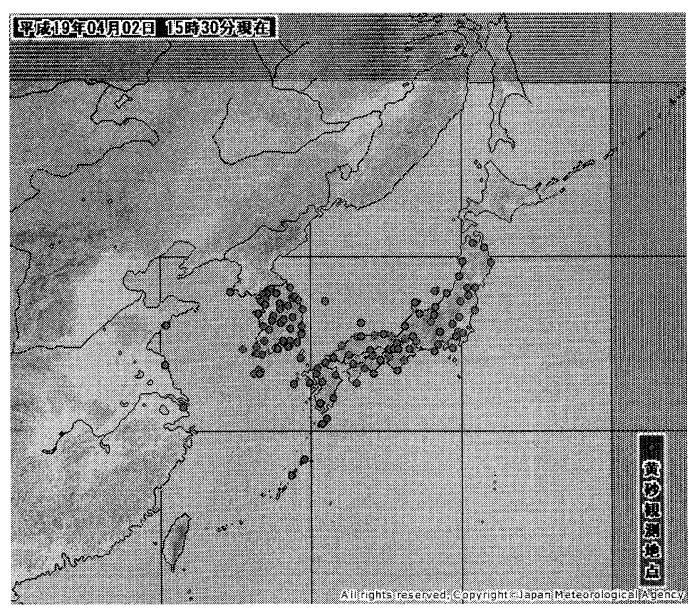

(a)



(b)

図 6. 気象庁黄砂情報 (2007 年 4 月 2 日の例)。(a) 黄砂観測実況図。点は黄砂が観測された観測点を示す。(b)黄砂予測図。 濃い黄砂(視程が $10 \mathrm{~km}$ 未満)を予測した領域を表示している。

学的な観点から挙げておく。

\section{気象モデルの巨大な格子内の非一様性}

現在の黄砂予測モデルの水平格子間隔は約 $110 \mathrm{~km}$ と、ダス卜発生の現象スケールと比較すると非常に 大きい。このため、モデルの格子で表現できない地 形や土地利用形態、土壌の状態、風速の違いなどが ダス卜発生量に大きな影響を及ぼしている可能性が ある。最近のモデルでは、格子内の風速の確率密度 分布を仮定した上でダス卜発生量を計算するなどの 工夫が試みられつつある ${ }^{35)}$

\section{Hot spot と局地風}

人工衛星による解析からは、ダストの発生源は乾 燥地域の中でも比較的狭い領域に限られており、周 りの地形よりも低くなっている凹んだ地点が多いこ とが明らかになっている。それらは「hot spot」とよ ばれており、河川の堆積物がたまった場所や干上が った湖などが多く、シルト(粒径 $1 / 16 \mathrm{~mm} \sim 1 / 256 \mathrm{~mm}$

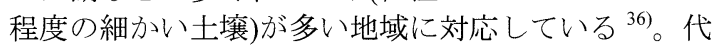
表的な hot spot としてはサ八ラ砂漠のチヤド湖や中 国のタクラマカン砂漠などが挙げられる。またこの ような地域では、地形の影響から山谷風のような熱 的な局地風や熱対流によって強風が起こりやすい可 能性も考えられる。このような地域における風環境 とダス卜発生の関係を明らかにするため、雲解像モ デルなどを用いた、より詳細な大気の振る舞いの研究 37) は今後とも必要だらう。

\section{熱対流・塵旋風によるダストの発生}

大規模な砂塵嵐は発達する低気圧に伴う強風によ って発生することが多いが、砂漠などでは、強い日 射の影響で対流活動が活発になり、スケールの小さ い強い渦を伴う上昇流によってダストが舞上げられ るという現象が頻繁に見られる。この現象は塵旋風
(ダストデビル)とよばれる。塵旋風に伴うダストの 発生量は明らかではなく、スケールが小さいために 現実的な数值モデルによる予測も難しい。今後、 LES などを用いた塵旋風の影響の研究を期待した い。

\section{現実的な土袞におけるダスト発生量}

これまでに考慮されている、ダスト発生量が摩擦 速度の 3〜4 乗に比例するという関係は、土壌粒子の 粒径を一定とした条件下で導かれている。現実には 土壌は大小様々な粒子でなりたっている。このよう に現実的な条件におけるダス卜発生量と摩擦速度の 関係は、最近の研究 ${ }^{38)}$ でようやく端緒についたばか りである。

さらに、現在の黄砂予報にはこれまでに述べたも のの他にも、様々な課題点がある。

\section{他のエーロゾルの影響と視程への換算}

現在、気象庁の黄砂予報では鉱物ダストのみが考 慮されているが、視程の悪化には人為起源物質など の他のエーロゾルの濃度も影響している。これまで にも、顕著な黄砂現象の事例で黄砂とともに大気污 染によるエーロゾルも同時に日本に輸送されている ことが報告されている ${ }^{39)}$ 。また、実際の気象官署で の観測は視程を基準に行われていることから、黄砂 現象の判定基準もダスト濃度のみではなく他のエー ロゾルの濃度も含め、放射計算によって視程に換算 した值を用いることが望まれる。

\section{黄砂発源地の現状の把握}

中国では近年の経済発展に伴い、農地転換や過放 牧などによる土地の劣化が進行している。その結果、 砂漠化・乾燥化が進み、ダストの発生量が増加して いると考えられている ${ }^{40)}$ 。また、晚冬から春季の初 
旬にかけては、植生量の変化、積雪量の変化や融雪 による土㙵水分の変化が大きい。このような地表面 の状況をリアルタイムで取得し、反映させることが 重要である。また、観測を基にした黄砂発源地の現 状をリアルタイムで取得するには、人工衛星データ による広域の地表面情報の解析や、現地データ入手 のための国際的な協力も欠かせない。

\section{ダスト分布のデータ同化}

現在の黄砂予測モデルでは気象場のデータ同化は 行っているが、ダスト濃度には観測結果は取り入れ られていない。そのため、数日前の誤差を引きずっ てしまい、モデルの誤差を修正できない。これまで に、TOMS Aerosol Index ${ }^{33)}$ 用いてダスト分布のデ

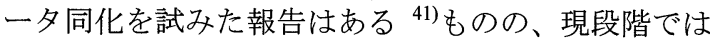
ダスト分布は不連続であることや、観測で入手でき る情報の限界から、ダスト濃度のデータ同化はまだ 実施できない状況である。衛星解析やライダー観測 の結果などを取り入れたダスト分布のデータ同化は 将来に向けての大きな課題点である。

\section{モデルの高解像度化と領域}

ダストの発生と輸送を精度良く表現するためには、 地表面の特性や地形をより詳細に表現できることが 望ましいが、高解像度の全球モデルは非常に大きな 計算機資源が必要となり、実現が困難である。東ア ジアにおける黄砂現象を考える場合は、中国および モンゴルの乾燥・半乾燥地帯を起源とするダストに よるものがほとんどであるため、例えば九州大学の CFORS モデル ${ }^{42)}$ のうに、黄砂の予測には領域気象 モデルを用いることが多い。限られた計算機資源で より高い精度の予測を行うには、領域気象モデルを 用いることが効果的な方法である。

しかしより広い領域にわたるダスト現象を考える 必要がある場合もある。例えば、2003 年 3 月 25 27 日に日本で観測された黄砂現象は、サハラ砂漠や中 東で発生した砂塵嵐によるダストであることが、モ

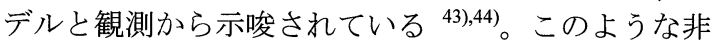
常に長距離のダストの影響を評価するためには全球 のモデルが不可欠である。全球と領域のモデルはそ れぞれの特徵を補完するように運用することが望ま しい。

\section{6. おわりに}

今後はより多くの黄砂現象に関して、衛星やライ ダ一、放射計などの観測手段を用いて検証し、精度 をさらに向上させることが必要である。また、他の エーロゾルの考慮や黄砂発源地の現状データの取り 込み、ダスト分布のデータ同化、モデルの高解像度 化などが将来の課題である。ダストなどのエーロゾ ルによる放射への影響は、気候スケールのみでなく、 日々の気象予報の時間・空間スケールにおいても影 響があるとの報告がある。最近のヨーロッパ中期予 報センター(European Center for Medium-Range Weather Forecasts, ECMWF)の例では、気象予報モデルの放射
過程に現実的なエーロゾル分布を用いると予報精度 が向上するという報告もなされている ${ }^{45)}$ 。将来的に は、黄砂予報モデルを数值気象予報モデルと統合す ることによって、気象予報・黄砂予報ともにより一 層の予報精度の向上が期待できるだろう。

\section{参考文献}

1). Charlson, R. J., J. E. Lovelock, M. O. Andreae and S.G.Warren, Oceanic phytoplankton, atmospheric sulphur, cloud albedo and climate. Nature, 326, 655-661, 1987

2). Twomey, S., Pollution and the planetary albedo. Atmos. Environ., 8, 1251-1256, 1974

3). Dentener, F. J., G. R. Carmichael, Y. Zhang, J. Lelieveld and P. J. Crutzen, Role of mineral dust aerosol as a reactive surface in the global troposphere. J. Geophys. Res., 101, 22869-22889, 1996

4). Martin, J. H. and S. E. Fitzwater, Iron-deficiency limits phytoplankton growth in the northeast Pacific subarctic. Nature, 331, 341-343, 1988

5). Hansen, J. and L. Nazarenko, Soot climate forcing via snow and ice albedos. Proc. Natl. Acad. Sci. USA 101, 423-428, 2004

6). Penner, J. E., M. Andreae, H. Annegarn, L. Barrie, J. Feichter, D. Hegg, A. Jayaraman, R. Leaitch, D. Murphy, J. Nganga and G. Pitari, Aerosols: Their direct and indirect effects. J. T. Houghton, Y. Ding, D. Griggs, M. Noguer, P. J. van der Linden, X. Dai, K. Maskell and C. A. Johnson, Eds., Climate Change 2001: The Scientific Basis, Contribution of Working Group I to the Third Assessment Report of the Intergovernmental Panel on Climate Change, Cambridge Univ. Press., New York, chapter 5, 289-348, 2001

7). 環境省，黄砂問題検討会報告書 (http://www.env.go.jp/earth/dss/report/), 2005

8). Tanaka, T. Y., $\quad$ K. Orito, T. T. Sekiyama, K. Shibata, M. Chiba and H. Tanaka, MASINGAR, a global tropospheric aerosol chemical transport model coupled with MRI/JMA98 GCM, Pap. Met. Geophys., 53, 119-138, 2003

9). Shibata, K., M. Deushi, T. T. Sekiyama and H. Yoshimura, Development of an MRI Chemical Transport Model for the Study of Stratospheric Chemistry, Pap. Met. Geophys., 55, 75-119, 2005

10). Tanaka T. Y. and M. Chiba, Global Simulation of Dust Aerosol with a Chemical Transport Model, MASINGAR, J. Meteorol. Soc. Japan, Vol. 83A, 255-278, 2005

11). Shibata, K., H. Yoshimura, M. Ohizumi, M. Hosaka and M. Sugi, A simulation of troposphere, stratosphere and mesosphere with an MRI/JMA98 GCM, Pap. Meteorol. Geophys., 50, $15-53,1999$

12). Staniforth, A. and Côté, J., Semi-Lagrangian integration schemes for atmospheric models - a review, Mon. Wea. Rev., 119, 2206-2223, 1991

13). Mellor, G. L. and T. Yamada, A hierarchy of turbulence closure models for planetary boundary 
layers. J. Atmos. Sci., 31, 1791-1806, 1974

14). Mahowald, N. M., P. J. Rasch and R. G. Prinn, Cumulus parameterizations in chemical transport models. J. Geophys. Res., 100, 26173-26189, 1995

15). Arakawa, A. and W. H. Schubert, Interaction of a cumulus ensemble with the large-scale environment, part I. J. Atmos. Sci., 31, 674-701, 1974

16). Cunningham, E., On the velocity of steady fall of spherical particles through fluid medium, Proc. Roy. Soc. London., A83, 357-365, 1910

17). Knudsen, M. and S. Weber, Luftwiderstand gegen die langsame Bewegung kleiner Kugeln, Ann. Phys. 36, 981-994, 1911

18). Wesely, M. L. and Hicks, B. B., Some factors that affect the deposition rates of sulfur dioxide and similar gases on vegetation, J. Air Pollut. Control Assoc., 27, 1110-1116, 1977

19). Giorgi, F. and W. L. Chameides, Rainout lifetimes of highly soluble aerosols and gases as inferred from simulations with a general circulation model, J. Geophys. Res. 91, 14367-14376, 1986

20). Seinfeld, J. H. and S. N. Pandis, Atmospheric chemistry and physics: From air pollution to climate change. A Wiely-Interscience publication, New York, NY, 1326pp., 1997

21). Bagnold, R. A.: The Physics of Blown Sand and Desert Dunes, Methuen \& Co. Ltd., London , 1941

22). Owen, P. R.: Saltation of uniform grains in air. $J$. Fluid. Mech. 20, 2, 225-242, 1964

23). Gillette, D.: A wind tunnel simulation of the erosion of soil: Effect of soil texture, sandblasting, wind speed, and soil consolidation on dust production, Atmos. Environ., 12, 1735-1743, 1978

24). Gillette, D.A. and Passi, R.: Modeling dust emission caused by wind erosion, J. Geophys. Res., 93, D11, 14233-14242, 1988

25). Shao, Y., Physics and Modelling of Wind Erosion. Vol. 23 of Atmospheric and oceanographic sciences library, Kluwer Academic Press, Dordrecht, the Netherlands, 393pp, 2000

26). Pye, K., Aeolian Dust and Dust Deposits. Academic Press, 1987

27). Tegen, I., I. Fung, Modeling of mineral dust in the atmosphere: Sources, transport, and optical thickness, J. Geophys. Res., 99, D11, 22897-22914, 1994

28). Takemura, T., H. Okamoto., Y. Murayama, A. Numaguti, A. Higurashi, T. Nakajima: Global three-dimensional simulation of aerosol optical thickness distribution of various origins, $J$. Geophys. Res., 105, D14, 17853-17873, 2000

29). Shao, Y., M. R. Raupach, J. F. Leys, A model for predicting aeolian sand drift and dust entrainment on scales from paddock to region, Aust. J. Soil. Res., 34, 309-342, 1996

30). Tanaka, T. Y., T. Aoki, H. Takahashi, K. Shibata, A. Uchiyama and M. Mikami, Study of the sensitivity of optical properties of mineral dust to the direct aerosol radiative perturbation using a global aerosol transport model, SOLA 3, 33-36, doi:10.2151/sola.2007-009, 2007

31). Sugimoto, N., Uno, I., Nishikawa, M., Shimizu, A., Matsui, I., Dong, X., Chen, Y., Quan, H.: Record heavy Asian dust in Beijing in 2002: Observations and model analysis of recent events, Geophys. Res. Lett., 30, 12, 1640 , doi:10.1029/2002GL016349, 2003

32). Chung, Y.-S., Kim, H.-S., Dulam, J., Harris, J.: On heavy dustfall observed with explosive sandstorms in Chongwon-Chongju, Korea in 2002, Atmos. Environ., 37, 3425-3433, 2003

33). Herman, J. R., P. K. Bhartia, O. Torres, C. Hsu, C. Seftor and E. Celarier, Global distribution of UV-absorbing aerosols from Nimbus 7/TOMS data, J. Geophys. Res. 102, 16911-16922, 1997

34). Network Center for EANET: Data Report on the Acid Deposition in the East Asian Region 2002, 2003

35). Cakmur, R. V., R. L. Miller and O. Torres, Incorporating the effect of small-scale circulations upon dust emission in an atmospheric general circulation model. J. Geophys. Res. 109, D07201, doi:10.1029/2003JD004067, 2004

36). Prospero, J. M., P. Ginoux, O. Torres, S. E. Nicholson, and T.E. Gill, Environmental characterization of global sources of atmospheric soil dust identified with the Nimbus 7 total ozone mapping spectrometer (TOMS) absorbing aerosol product. Rev. Geophys. 40, 1002, doi:10.1029/2000RG000095, 2002

37). Takemi, T., Explicit simulations of convective-scale transport of mineral dust in severe convective weather. J. Meteor. Soc. Japan, 83A, 187-203, 2005

38). Shao, Y., A similarity theory for saltation and application to aeolian mass flux. Bound. Layer Meteor. 115, 319-338, 2005

39). Takemura, T., I. Uno, T. Nakajima, A. Higurashi, I. Sano, Modeling study of long-range transport of Asian dust and anthropogenic aerosols from East Asia, Geophys. Res. Lett., 29, 24, 2158, doi:10.1029/2002GL016251, 2002

40). Gong, S.L., Z. Y. Zhang, T.L. Zhao, L.A. Barrie, Sensitivity of asian dust storm to natural and anthropogenic factors, Geophys. Res. Lett. 31, 7, L07210, doi:10.1029/2004GL019502, 2004

41). Alpert, P., S. O. Krichak, M. Tsidulko, H. Shafir, J. H. Joseph, A dust prediction system with TOMS initialization, Mon. Wea. Rev., 130, 2335-2345, 2002

42). Uno, I., G.R. Carmichael, D.G. Streets, Y. Tang, J.J. Yienger, S. Satake, Z. Wang, J.-H. Woo, S. Guttikunda, M. Uematsu, K. Matsumoto, H. Tanimoto, K. Yoshioka, T. Iida,d Regional chemical weather forecasting system CFORS: Model descriptions and analysis of surface observations at Japanese island stations during the ACE-Asia experiment, J. Geophys. Res., 108, D23, 8668, doi:10.1029/2002JD002845, 2003 
43). Tazaki, K., R. Wakimoto, Y. Minami, M. Yamamoto, K. Miyata, K. Sato, I. Saji, S. K. Chaerun, G. Zhou, T. Morishita, R. Asada, H. Segawa, H. Imanishi, R. Kato, Y. Otani and T. Watanabe, Transport of carbon-bearing dusts from Iraq to Japan during Iraq's war. Atmos. Environ. 38, 2091-2109, 2004

44). Tanaka, T. Y., Kurosaki, Y., Chiba, M., Matsumura, T., Nagai, T., Yamazaki, A., Uchiyama, A., Tsunematsu, N., Kai, K., Possible transcontinental dust transport from North Africa and the Middle East to East Asia. Atmos. Environ. 39, 3901-3909, 2005

45). Tompkins, A. M., C. Cardinali, J.-J. Morcrette and M. Rodwell, Influence of aerosol climatology on forecasts of the African Easterly Jet, Geophys. Res. Lett., 32, L10801, doi:10.1029/ 2004GL022189, 2005 